\title{
The Effect of CFO Demographics on Fraudulent Financial Reporting
}

\author{
Yulia Frischanita and Yustrida Bernawati \\ Fakultas Ekonomi dan Bisnis, Universitas Airlangga \\ Email: yulia.frischanita-2018@feb.unair.ac.id, yustrida-b@feb.unair.ac.id
}

\begin{abstract}
Penelitian ini bertujuan untuk menguji pengaruh demografi CFO terhadap kecurangan laporan keuangan. Hasil penelitian ini berkontribusi untuk memberikan rekomendasi bagi perusahaan agar dapat meningkatkan pemilihan CEO dan CFO serta struktur tata kelola yang dirancang untuk mencegah tindakan yang illegal. Sampel dalam penelitian ini adalah perusahaan manufaktur yang terdaftar di Bursa Efek Indonesia tahun 2016-2018 dengan data sebanyak 308 dan pengujian hipotesis menggunakan teknik analisis regresi berganda. Hasil pengujian menunjukkan bahwa umur CFO berpengaruh terhadap kecurangan laporan keuangan. Semakin dewasa CFO semakin berpengaruh terhdap kecurangan laporan keuangan. Hasil lain menunjukkan bahwa tingkat pendidikan, gender dan pengalaman CFO tidak berpengaruh terhadap kecurangan laporan keuangan. Variable control yang digunakan yaitu ROA berpengaruh positif terhadap kecurangan laporan keuangan. Sedangkan ukuran perusahaan dan leverage berpengaruh negatif terhadap kecurangan laporan keuangan.
\end{abstract}

Keywords: kecurangan laporan keuangan, umur CFO, tingkat pendidikan $\mathrm{CFO}$,gender $\mathrm{CFO}$ dan pengalaman $\mathrm{CFO}$

Abstract: This study aims to examine the effect of CFO demographics on financial statement fraud. The results contribute to companies for increasing CEO and CFO elections and corporate governance designed to prevent illegal actions. The sample in this study was manufacturing companies listed on the Indonesia Stock Exchange in 2016-2018 with 308 data and hypothesis testing using multiple regression analysis techniques. The test results show that the age of the CFO affects the fraudulent financial statements. More mature the $\mathrm{CFO}$ engage with fraudulent financial statements. Other results indicate that the level of education, gender and experience of the CFO have no effect on financial statement fraud. The control variable used is ROA which has a positive effect on financial statement fraud. While company size and leverage have a negative effect on financial statement fraud.

Keyword: fraudulent financial statement, Age CFO, Education Level CFO, gender CFO. Experience CFO.

\section{INTRODUCTION}

Fraudulent financial statements are one of the white-collar crimes that cause losses of up to billions of rupiah. The Association of Certified Fraud Examiners (ACFE) surveyed various types of fraud in 2016. It gave the result that financial statement fraud found to be 
only $2 \%$, but the resulting losses were the most dominant, namely exceeding Rp10 billion (ACFE Indonesia, 2017). Fraudulent financial reporting often occurs even the most recent one happened in the 2018 financial report fraud scandal committed by the management of PT. Garuda Indonesia. In 2017 PT. Garuda Indonesia recorded a loss of USD216.5 million, but in 2018 the company recorded a profit of up to USD809.8. The examination result revealed that PT. Garuda Indonesia cheated financial reporting, namely window dressing, by recognizing all revenue that would occur in 2019 in 2018. As a result, the board of directors of PT. Garuda Indonesia, as the party responsible for the truth of the financial statements, is required to pay a fine of up to Rp 100 million (Hartomo, 2019).

The directors' responsibility for the accuracy of financial statements publicly is regulated in Sarbanes Oxley Section 302. The regulation requires that the CEO and CFO be responsible for the accuracy and documentation of the submission of financial statements and internal control structures to the SEC (Sarbanes Oxley Act, 2002). The regulation explained that the CFO, as the party directly in charge of accounting and finance, must take appropriate measures not to mislead users of financial statements. Not only the Sarbanes Oxley Act, but Indonesia also applies the regulation. Financial Services Authority Regulation Number 75 / Pojk.04/2017 Regarding the Responsibilities of the Board of Directors for Financial Statements explains that the Board of Directors is responsible for the truth of the financial statements presented as evidenced by the Directors' report and signed by the Directors. The regulation also explained that the Directors are ready to bear the losses that may cause. Decision making chosen by the CFO influences by the development of its cognitive value, which is shaped by individual demographic characteristics.

Upper echelon theory explains that the executive's interpretation of a situation influences by individual experiences, values, and characteristics (Hambrick and Mason, 1984). The executive will face certain cases where the executive is required to make a decision. The executive will always carry their characteristics in decision-making so that the decision reflects the uniqueness of the decision-maker. The self- components consist of functional footprint, age, work experience, education level, gender, and others. The value of cognition that is formed by self-characteristics will make executives know various alternative decisions and inherent risks so that in the end, executives will choose arrangements according to their preferences.

Research on the demographic characteristics associated with fraudulent financial reporting has conducted several times. CFO, who has the right level of education, will have moral development and the ability to process and analyze useful information (Cheng et al., 2010; Sun et al., 2017; Troy et al., 2011). The individual can distinguish alternative decisions that can provide benefits and minimal risk (Papadimitri et al., 2020). Similarly, CFO women who have more conservative characteristics behave ethically and avoid risk (Barua et al., 2010; Francis et al., 2015; Sun et al., 2017). These results are also supported by research by (Capezio and Mavisakalyan, 2016), which stated that the more women in the board of directors, the smaller the financial statement fraud. CFOs who have a lot of experience will be more cautious and more concerned about the security of their careers, especially if they are nearing the end of their term of office (Rashad, 2014; Yuehua, 2018). (Huang et al., 2012) also explained that executives with more experience maintain their reputation so that they will not make risky decisions. The level of one's experience contributes to the development of individual morals. (Ortiz et al., 2019) stated that CFOs with little experience would be risk-takers because of the lack of knowledge about the 
company. Based on some of these studies, it can indicate that CFOs who have a high level of education, a lot of experience, female and have a long career will not decide to cheat financial statements. Fraudulent financial reporting can pose a higher risk and can even threaten and damage the $\mathrm{CFO}$ career.

Several other studies have had results that do not support statements regarding fraudulent financial statements' demographic characteristics. Research conducted by (Bertrand and Schoar, 2003) and (Daboub et al., 1995) proved that managers with MBA education levels are involved in financial statement fraud. That is because MBA students taught to be profit-oriented and ignore ethics. Besides, MBA graduated take aggressive and risky decisions. Research conducted by (Yuehua et al., 2018) had given a different result where more experienced executives will be involved in fraud because the executive has the communication skills to compromise his actions with the supervisory board. Finally, research conducted by (Liao et al., 2019) has shown that there is no relationship between gender and financial reporting fraud.

This research is the development of a study conducted by (Sun et al., 2017) with differences in research on the measurement of fraudulent financial statements. (Sun et al., 2017) use dummy variables to measure financial statement fraud. That is because, in China, there are AAER institutions that publish companies that commit fraud. This study uses the F-score as a measurement of financial reporting fraud due to the limited disclosure of companies that commit financial reporting fraud in Indonesia. (Dechow et al., 2011), which uses it as a red flag, indicating that the company is cheating financial reporting. This study also uses the CFO experience level variable that refers to research conducted by (Troy et al., 2011).

\section{THEORETICAL REVIEW}

Upper Echelons Theory. Upper echelons theory developed by (Hambrick and Mason, 1984) explained that executives' cognition, values, and perceptions could predict strategic choices and performance, including the tendency to cheat financial statements. The CEO faces several distinctly complex situations consisting of far more phenomena than they can understand. Decision-making brings a cognitive basis and values to a decision, which creates a barrier between the case and the event's perception. Managers or members cannot observe every aspect of the organization and the environment. Manager's opinion is limited because a person selectively feels only a few phenomena that include in the field of the manager's vision. The information chosen for processing interprets through filters arranged by one's cognitive base and values. Managers' perceptions of these situations combine with one's costs to provide the basis for strategic choices. A person's values can influence opinions or even directly enter into strategic decisions because theoretically, decisionmakers can achieve a set of perceptions that suggest individual options but discard those choices based on one's values (Troy et al., 2011).

(Troy et al., 2011) researched demographic characteristics that contribute to the development of one's cognition so that it influences decision making. (Troy et al., 2011) explained that executives who are mature, have a high level of education, and who are women are less likely to be involved in financial statement fraud. That is because they have higher ethical standards. They focus on financial security and their careers to avoid risky decisions (Nasution and Jonnergård, 2017; Rashad, 2014; Yuehua et al., 2018) which can 
threaten their reputation and will also be more ethical (Huang et al., 2012; Sundaram and Yermack, 2007). Conservative and moral characteristics and risk aversion are also shared by female CFOs who are more traditional, ethical, and risk-averse than men (Sun et al., 2017). Experienced CFOs will also share conservative attitudes because of their knowledge and good self-management (Ortiz et al., 2019).

Conceptual framework. The demographic characteristics of CFO are age, level of education, and gender associated with the selection of strategic decisions of the company. CFO demographics describe a person's cognition in filtering and interpreting information so that it affects the decisions taken (Hambrick and Mason, 1984). CFO who are already mature and have a high level of education will experience the development of good cognition. They will have the skills and ability to process useful information (Cheng et al., 2010; Sun et al., 2017). They will look at each alternative based on the risks inherent in each option. CFO women will be more conservative, causing CFO will eventually avoid risky decisions such as fraudulent financial statements (Barua et al., 2010; Capezio and Mavisakalyan, 2016; Francis et al., 2015). The knowledge the CFO possesses from its shared experience will make the CFO have good self-management to avoid risky decisions (Ortiz et al., 2019). Career and reputation security will threaten if they commit financial reporting fraud, so they tend to avoid it. This study also uses three control variables, namely ROA, Leverage, and Company Size. Companies that have excellent performance, low debt levels, and are small-sized companies tend not to cheat financial statements (Hajek and Henriques, 2017; Noble, 2019; Sun et al., 2017). The explanation is illustrated in the conceptual framework in Figure 1 below:

Figure 1. Conceptual Framework

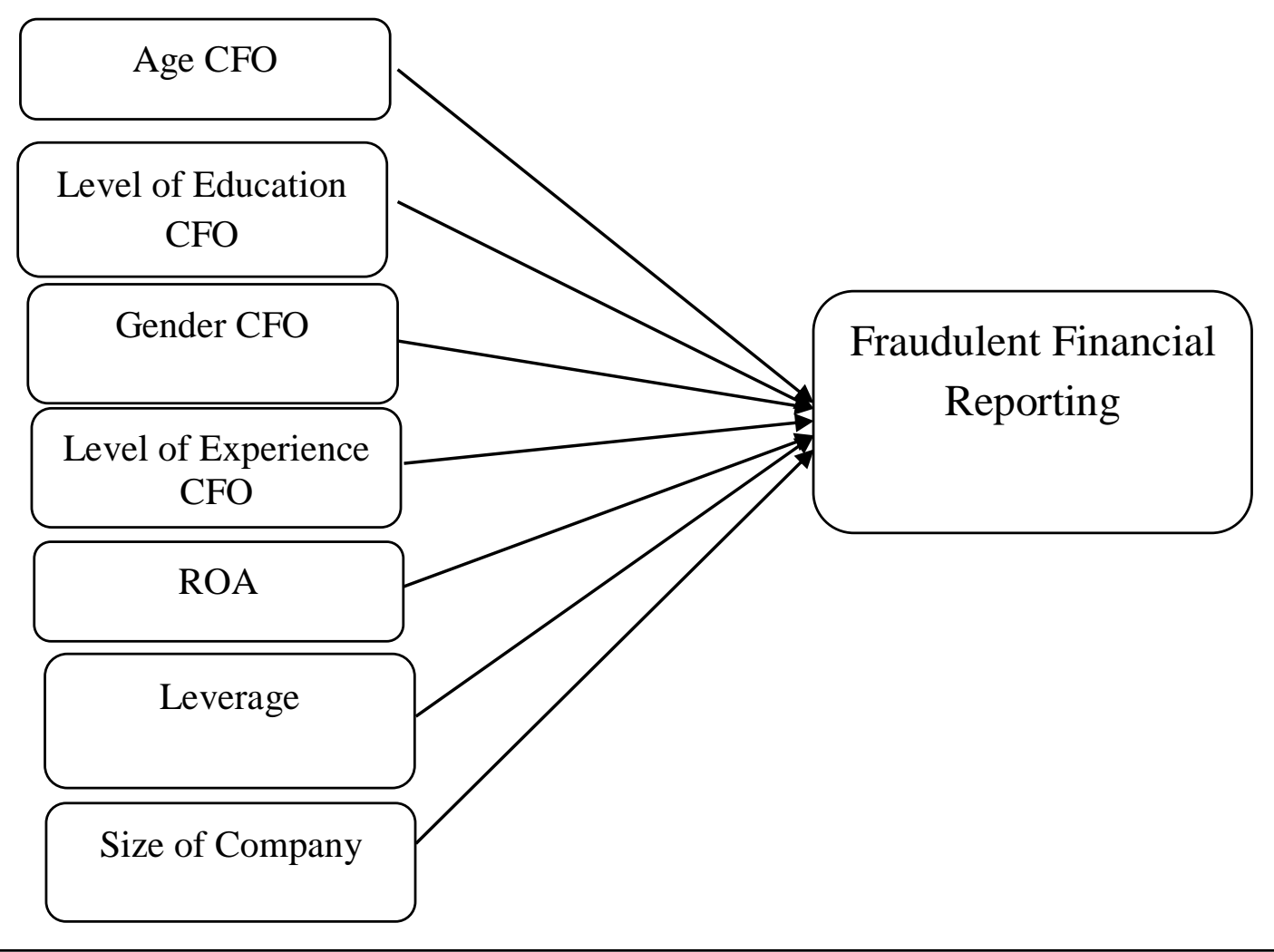


Hypothesis Development. (Hambrick and Mason, 1984) stated that executive demographic characteristics could influence the development of their cognitive values so that they can change the interpretation of the situation and influence the decisions taken. Some demographic characteristics tested by (Hambrick and Mason, 1984) are age, gender, educational background, and level of executive experience. This study will use the demographic characteristics as an independent variable that thought to influence the decision of the CFO to commit financial statements. Here is the development of his hypothesis:

Age of CFO and Financial Statement Cheating. Older CFOs will not be involved with financial statement fraud because CFOs will maintain the security of their positions in the company (Hambrick and Mason, 1984). They also have more ethical behavior so that every decision will be taken precisely (Rashad, 2014). CFO will consider all the negative consequences of alternative decision choices. It makes the CFO will not cheat financial statements because the action has a high risk and threatens the reputation of the $\mathrm{CFO}$ (Huang et al., 2012; Sundaram and Yermack, 2007).

(Hambrick and Mason, 1984), through upper echelon theory, stated that younger executives have a risky strategy commonly referred to as "youthful ignorance." A young person feels able to assume a higher risk for his decision. It was also made clear by the research of (Sproten et al., 2018), who reported that young individuals tend to take risky decisions, especially when these individuals face ambiguity due to environmental uncertainty. Younger managers will rush into decision-making so they will not consider the amount of risk they will bear.

The white-collar crime research conducted by (Price and Norris, 2009) showed that younger managers are more vulnerable to social and organizational pressure. As a person ages, they become more experienced, and decision-making skills also increase. Younger executives do not exhibit higher ethical sensitivity than older executives (Xu et al., 2018). It can make young executives quickly involved in illegal actions such as fraudulent financial reporting. Based on this description, the following hypotheses emerge:

H1: CFO age affects financial reporting fraud.

Educational Level and Financial Statement Cheating. A CFO with the right level of education will not be involved in financial statement fraud because it can manage user information and a more ethical attitude. The level of education shows a person's abilities and skills to influence a company's strategic decision choices (Hambrick and Mason, 1984). (Sun et al., 2017) stated that top executives who have better education could quickly absorb new ideas and implement more effective strategies. Executives with higher levels of education have greater cognitive complexity. It makes the executive able to distinguish between various alternative decisions and the risks that accompany each alternative. The ability to process information has made executives consider decision choices and their risks and choose resolutions that can optimize company performance but have a lower level of risk.

The ethical attitude held by the executive will prevent the executive from wanting to carry out illegal actions such as fraudulent financial reporting. (Cheng et al., 2010) showed that executives with proper education levels would produce better business performance and 
have a more ethical attitude. If the executive does not commit financial reporting fraud, the financial statements presented to the public will show the company's real condition so that it will not mislead users of financial statements. Based on this description, the following hypothesis built:

H2: CFO Education Level affects financial reporting fraud.

Gender in CFO and Financial Reporting Fraud. (Heminway, 2007) provided empirical evidence that women tend not to be involved in financial statement fraud. The statement reinforced by research conducted by (Nasution and Jonnergård, 2017) explaining the gender differences associated with moral development, moral sensitivity, and risk-taking tendencies. Three variations are associated with characteristics, attitudes of conservatism, risk avoidance, and different levels of ethical behavior in gender. (Sun et al., 2017) stated differences in behavior between genders have necessary implications for the quality of financial statements. Male executives are more likely to make mistakes than female executives. (Schnatterly et al., 2018) suspected the possibility because of the gender differences so that there are differences in attitudes in the face of temptation and self-control. Illegal actions such as cheating financial statements are contrary to ethical behavior held by women, so women tend to be more trustworthy than men. Apart from that, (Barua et al., 2010) proved that women would provide high-quality financial statements and avoid earnings management because earnings management contains a high level of risk. The description encourages researchers to construct hypotheses such as the following:

H3: Gender in CEO influences Financial Reporting Fraud.

Level of CFO Experience and Financial Reporting Fraud. (Hambrick and Mason, 1984) stated that work experience is related to variations in decisions based on interpretations and perceptions about an issue. (Troy et al., 2011) reported that long work experience makes the CEO have a lot of information, and the CEO can utilize it when faced with a problem. The amount of information held makes the executive have self-regulation and will consider his decision from various aspects so that the decision taken will have a positive impact on himself. An executive with a level of functional experience can maintain their career at the company (Zhang et al., 2008). They will avoid decisions that can threaten their reputation, such as being involved in financial statement fraud. Executives who have not had a long career with a commitment to the company will be aggressive and take the opportunity to enrich themselves so that the possibility of being involved in financial statement fraud will be higher. If the fraud is detected, they feel less loss, so rationalize these illegal actions. The CEO's who was naive would be finally used to justify the fraudulent activities of the financial statements. Based on this description, a hypothesis emerged:

H4: CFO Work Experience influences financial reporting fraud.

\section{METHODOLOGY}

This study uses multiple regression analysis to test hypotheses and determine the direction of the relationship between CFO Demographic variables and Financial Reporting 
Fraud. This type of research is quantitative research. The data used is secondary data, taken from financial reports and annual reports obtained from the Indonesia Stock Exchange website www.idx.co.id. The population of this research is manufacturing companies listed on the Indonesia Stock Exchange from 2016-2018. The sample was chosen based on the following criteria:

1. Companies that provide complete data during the research year,

2. Companies that publish financial and annual reports on www.idx.co.id or the company's website

3. Have a positive ROA

The population was 402 , and after selection based on the criteria above, a final sample of 308 observational data obtained.

This study uses three independent variables: Age of CFO, Level of Education of CFO, and gender of CFO. The age of the CFO is the longevity of the lifetime of the CFO in year t. The age of the CFO was measured using the age of the CFO in the year of measurement refers to the research of (Sun et al., 2017), as follows:

\section{Age of CFO = age of CFO in year t.}

CFO education level is the level of education that has been taken by the CFO (Troy et al., 2011). Education level is measured using measurements that refer to (Sun et al., 2017):

\section{Level of Education CFO $=0$ if not a graduate below High Scholl, 1 if a high school graduate; 2 if the Diploma graduates; 3 if Bachelor graduates; 4 if a graduate is a Masters; 5 if a Doctorate graduate.}

Gender in CFO is a dummy variable that showed gender differences in CFO (Sun et al., 2017). Gender measurements come from (Sun et al., 2017) as measured by dummy variables:

\section{Gender in $\mathrm{CFO}=1$ if female and 0 if male.}

The CEO experience level is the length of time a person has held an executive position (Troy et al., 2011). This study used the CFO experience level variable, whose measurements come from (Troy et al., 2011) modified based on Indonesia's situation:

\section{CEO Experience Level $=$ how long someone has held a functional position}

Financial reporting fraud is the fraud that occurs because an employee intentionally removes material information in the financial statements and violates the General Acceptable Accounting Principles that cause material misstatement that can affect economically (Dechow et al., 2011). Measurement of financial statement fraud calculated using calculations developed by (Dechow et al., 2011), namely the F score. F-score is a "red flag" for the tendency of financial statement fraud. The F-Score has an accuracy of $62 \%$ in 
detecting financial reporting fraud. The calculation model is more updated than the Beneish Model, which also uses to measure financial reporting fraud. F-Score calculations developed by (Dechow et al., 2011) describe as follows:

F-Score $=$ Accrual Quality + Financial Performance $+\%$ Soft Assets

Information:

Accrual Quality is proxied by RSST Accrual. The following is the RSST Accrual calculation.

$$
\text { RSSTAccrual }=\frac{\Delta \mathrm{WC}+\Delta \mathrm{NCO}+\Delta \mathrm{FIN}}{\text { Average Total Asees }}
$$

Information:

WC $($ Working Capital $)=$ Current Assets - Current Liabilities

NCO $($ Non-Current Operating Accrual $)=($ Total Assets - Current Assets - Investment and Advances) - (Total Liabilities - Current Liabilities - Long-Term Debt)

FIN $($ Financial Accruals $)=$ Total Investment - Total Liabilities

Rata-rata total asset $=\frac{\text { Total Early Asset }+ \text { Total Final Asset }}{2}$

Then do the financial performance calculations. Here are the calculations:

Financial performance $\boldsymbol{=}$ changes in receivables + changes in inventory + changes in sales cash + changes in income

Information:

Change in Receivables $=\frac{\Delta \text { Receivable }}{\text { Average Total Asset }}$

Inventory Changes $=\frac{\Delta \text { Inventory }}{\text { Average Total Asset }}$

Change in Sales Cash $=\frac{\Delta \text { Sales }}{\text { Sales }(\mathrm{t})}-\frac{\Delta \text { Receivable }}{\text { Reveivable }(\mathrm{t})}$

Change in ROA $=\frac{\text { Profit }(t)}{\text { Average Total Asset }(\mathrm{t})}-\frac{\text { Profit }(t-1)}{\text { Average Total Asset }(t-1)}$ 
$\%$ Soft Asset $=\frac{\text { Total Asset }- \text { PP\&E-Cash and cash equivalents }}{\text { total Asset }}$

This study uses control variables ROA, leverage, and firm size. ROA is one of the profitability ratios, which is the primary source of guarantee of the company's ability to meet long-term interest and principal payments (Subramanyam, 2014). ROA measurement refers to (Subramanyam, 2014):

ROA $=\frac{\text { Net Profit in year } t}{\text { Total Assets in year } t}$

Leverage is the use of debt to increase income (Subramanyam, 2014). Excessive debt limits management initiative and flexibility to pursue profitable opportunities. Following is the measurement of leverage from (Sun et al., 2017):

Leverage $=\frac{\text { Total Payables in year } \mathrm{t}}{\text { Total Asset in year } \mathrm{t}}$

Company size is a fundamental characteristic of a company. Company size refers to measurements in the research Sun et al. (2017), as follows:

\section{Company Size $=$ Ln total assets}

Data analysis techniques began with descriptive statistics to provide an overview of the CFO's age, the level of education of the CFO, gender of the CFO, and financial reporting fraud. Furthermore, hypothesis testing will perform using multiple regression analysis. Regression models are as follows:

$\mathrm{F}$-Score $=1.592+0.008 \mathrm{AGE}+0.014 \mathrm{EDU}+0.086 \mathrm{GEN}-0.03 \mathrm{EXP}+0.562 \mathrm{ROA}-$ 1.181LEV - 0.046FSIZE +

\section{Information:}

F-Score $=$ Measurement of Financial Reporting Fraud by Dechow et al. (2011)

$\mathrm{AGE}=$ Age of $\mathrm{CFO}$

$\mathrm{EDU}=\mathrm{CFO}$ Education Level

$\mathrm{GEN}=$ Gender in $\mathrm{CFO}$

$\mathrm{EXP}=\mathrm{CFO}$ Experience Level

ROA $=$ Return of Assets

LEV = Leverage

FSIZE = Company Size 


\section{THE RESULT OF STATISTICAL TESTS}

Data analysis starts from descriptive statistics, correlation tests, and hypothesis testing. The following are the results of the test:

Table 1. Descriptive Statistics of Research Variables

Descriptive Statistics

\begin{tabular}{l|c|c|c|c|c}
\hline & $\mathbf{N}$ & Minimum & Maximum & Mean & Std. Deviation \\
\hline AGE & 308 & 30.00 & 76.00 & 51.6234 & 8.19277 \\
\hline EDU & 308 & 2.00 & 5.00 & 3.3377 & .56177 \\
\hline EXP & 308 & 4.00 & 47.00 & 25.0812 & 7.86510 \\
\hline ROA & 308 & .00 & .92 & .0740 & .09693 \\
\hline LEV & 308 & .06 & 4.90 & .4726 & .37932 \\
\hline FSIZE & 308 & 22.95 & 32.24 & 28.3639 & 1.69370 \\
\hline FSCORE & 308 & .00 & 2.29 & .6619 & .41992
\end{tabular}

Source: (data processed in 2020)

Based on table 1, the total sample used in this study is 308 observational data after removing data that have a negative ROA value. This study showed the age value of CFO (AGE) has a minimum value of 30 years, a maximum value of 76 , and the average age of the CFO is 52 years. The level of education of the CFO (EDU) has a minimum value 2, which means that the minimum education level of the CFO is high school and has a maximum value, five, namely the Doctor. The lowest level of CFO education (EXP) is four years, and the longest is 47 years, with an average experience of 25 years. ROA has a minimum value of 0.00 and a maximum value of 0.92 , with an average of 0.07 . Leverage (LEV) has a minimum value of 0.06 , a maximum value of 4.90 , and an average value of 0.47. Company size (FSIZE) has a minimum value of 22.95 and a maximum value of 32.24 , while the average value indicates a value of 28.36. Meanwhile, the F-score (FSCORE) used as a red-flag for financial reporting fraud shows a minimum value of 0.00 and a maximum value of 2.29, while the average value of the F-Score is 0.66 .

Table 2. Statistics on Frequency of Gender Variables

GEN

\begin{tabular}{l|c|c}
\hline & Frequency & Percentage \\
\hline Male & 249 & 80.8 \\
\hline Female & 59 & 19.2 \\
\hline Total & 308 & 100.0 \\
\hline
\end{tabular}

Source: (data processed in 2020)

Table 2 showed a description of the gender variable CFO (GEN) described through frequency statistics: CFOs of males were 249 people or $80.8 \%$, while CFOs of females were 59 people or $19.2 \%$. 
Table 3. Variables Test of Pearson Correlation

Correlations

\begin{tabular}{|c|c|c|c|c|c|c|c|c|c|}
\hline & & $\overline{\text { AGE }}$ & EDU & GEN & EXP & $\overline{\text { ROA }}$ & LEV & FSIZE & $\begin{array}{c}\text { FSCO } \\
\text { RE }\end{array}$ \\
\hline \multirow{3}{*}{ AGE } & $\begin{array}{l}\text { Pearson } \\
\text { Correlation }\end{array}$ & 1 & -.079 & -.052 & .041 & -.036 & .084 & .108 & $.118^{*}$ \\
\hline & Sig. (2-tailed) & & .166 & .361 & .472 & .528 & .140 & .058 & .039 \\
\hline & $\mathrm{N}$ & 308 & 308 & 308 & 308 & 308 & 308 & 308 & 308 \\
\hline \multirow{3}{*}{ EDU } & $\begin{array}{l}\text { Pearson } \\
\text { Correlation }\end{array}$ & -.079 & 1 & -.028 & .090 & $.134^{*}$ & $.125^{*}$ & .064 & -.016 \\
\hline & \begin{tabular}{|l} 
Sig. (2-tailed) \\
\end{tabular} & .166 & & .621 & .117 & .019 & .028 & .263 & .773 \\
\hline & $\mathrm{N}$ & 308 & 308 & 308 & 308 & 308 & 308 & 308 & 308 \\
\hline \multirow{3}{*}{ GEN } & \begin{tabular}{|l} 
Pearson \\
Correlation \\
\end{tabular} & -.052 & -.028 & 1 & .012 & -.007 & -.027 & $-.125^{*}$ & .098 \\
\hline & Sig. (2-tailed) & .361 & .621 & & .837 & .898 & .642 & .028 & .087 \\
\hline & $\mathrm{N}$ & 308 & 308 & 308 & 308 & 308 & 308 & 308 & 308 \\
\hline \multirow{3}{*}{ EXP } & $\begin{array}{l}\text { Pearson } \\
\text { Correlation }\end{array}$ & .041 & .090 & .012 & 1 & .000 & -.031 & .071 & -.049 \\
\hline & Sig. (2-tailed) & .472 & .117 & .837 & & .998 & .589 & .211 & .392 \\
\hline & $\mathrm{N}$ & 308 & 308 & 308 & 308 & 308 & 308 & 308 & 308 \\
\hline \multirow{3}{*}{ ROA } & \begin{tabular}{|l|} 
Pearson \\
Correlation
\end{tabular} & -.036 & $.134^{*}$ & -.007 & .000 & 1 & -.070 & $.126^{*}$ & $.114^{*}$ \\
\hline & Sig. (2-tailed) & .528 & .019 & .898 & .998 & & .218 & .027 & .046 \\
\hline & $\mathrm{N}$ & 308 & 308 & 308 & 308 & 308 & 308 & 308 & 308 \\
\hline \multirow{3}{*}{ LEV } & \begin{tabular}{|l|} 
Pearson \\
Correlation \\
\end{tabular} & .084 & $.125^{*}$ & -.027 & -.031 & -.070 & 1 & .007 & $-.159^{* * *}$ \\
\hline & Sig. (2-tailed) & .140 & .028 & .642 & .589 & .218 & & .908 & .005 \\
\hline & $\mathrm{N}$ & 308 & 308 & 308 & 308 & 308 & 308 & 308 & 308 \\
\hline \multirow{3}{*}{ FSIZE } & \begin{tabular}{|l|} 
Pearson \\
Correlation
\end{tabular} & .108 & .064 & $-.125^{*}$ & .071 & $.126^{*}$ & .007 & 1 & $-.167^{* *}$ \\
\hline & Sig. (2-tailed) & .058 & .263 & .028 & .211 & .027 & .908 & & .003 \\
\hline & $\mathrm{N}$ & 308 & 308 & 308 & 308 & 308 & 308 & 308 & 308 \\
\hline \multirow{3}{*}{ FSCORE } & \begin{tabular}{|l|} 
Pearson \\
Correlation \\
\end{tabular} & $.118^{*}$ & -.016 & .098 & -.049 & $.114^{*}$ & $-.159^{* *}$ & $-.167^{* *}$ & 1 \\
\hline & Sig. (2-tailed) & .039 & .773 & .087 & .392 & .046 & .005 & .003 & \\
\hline & $\mathrm{N}$ & 308 & 308 & 308 & 308 & 308 & 308 & 308 & 308 \\
\hline
\end{tabular}

*. Correlation is significant at the 0.05 level (2-tailed).

**. Correlation is significant at the 0.01 level (2-tailed).

Source: (data processed in 2020)

Table 3 showed that the result of the Pearson Correlation, the strength of the relationship between each variable. AGE has a close relationship with FSCORE of 0.118 or $1.18 \%$. And ROA has a positive correlation of 0.114 or $1.14 \%$ with FSCORE. Moreover, LEV has a negative correlation with FSCORE of 0.159 or $1.59 \%$. FSIZE has a negative relationship with FSCORE of 0.167 or $1.67 \%$, whereas EDU and GEN have a less strong correlation with FSCORE. 
Table 4. Result of Multiple Regression Analysis

\begin{tabular}{l|c|c|c|c}
\hline \multicolumn{1}{c|}{ Model } & B & Std. Error & t & Sig. \\
\hline (Constant) & 1.592 & .426 & 3.739 & .000 \\
AGE & .008 & .003 & 2.952 & .003 \\
EDU & .014 & .042 & .326 & .744 \\
GEN & .086 & .059 & 1.458 & .146 \\
EXP & -.003 & .003 & -.905 & .366 \\
ROA & .562 & .242 & 2.320 & .021 \\
LEV & -.181 & .062 & -2.939 & .004 \\
FSIZE & -.046 & .014 & -3.334 & .001 \\
\hline N & \multicolumn{3}{|c}{0.000} & \\
F & \multicolumn{3}{|c}{0.080} \\
R & \multicolumn{3}{|c}{0.265} \\
Normality & \multicolumn{5}{|c}{} \\
\hline
\end{tabular}

Source: (data processed in 2020)

CFO (AGE), education level CFO (EDU), and gender CFO (GEN), ROA, leverage (LEV), and company size (FSIZE) against Fraudulent Financial Reporting (F-Score). The result showed that the F-value used for the accuracy test of the model shows a value of 0.00 smaller than the significance value, so it can conclude that the regression model is fit and can interpret. The R2 value showed some 0.08 , which means that the independent variable can explain the variability of the dependent variable by 0.08 or $8 \%$, while variables outside the model explain $92 \%$. Normality showed the value of 0.0265 above the significance of $5 \%$ so that it can conclude that the data regularly distributes. Hypothesis test showed that AGE has a significance value below $\alpha 0.05$, so it can find that the age of CFO affects the fraudulent financial statements or $\mathrm{H} 1$ is accepted. EDU, GEN, and EXP have a significance value of more than $\alpha$ of 0.05 , so it can conclude that the level of education of the CFO, the gender of the CFO and the level of experience of the CFO do not affect financial reporting fraud or $\mathrm{H} 2, \mathrm{H} 3$ and $\mathrm{H} 4$ rejected. All control variables: ROA, LEV, and FSIZE have a significance value of less than 0.05 , so it can conclude that all control variables influence financial statement fraud.

\section{DISCUSSION}

The statistical result showed that Hypothesis 1 is accepted: the age of CFO has a positive influence on financial statement fraud. This result supported research conducted by (Yuehua et al., 2018). (Yuehua et al., 2018) explained that when executives have a more mature age, they will not hesitate to commit fraud. That is because mature executives have the skills to interact with the supervisory board. The executive can damage the oversight system in governance because of their ability to negotiate oversight conducted by the board. The average age of the CFO was 52 years, indicating the age before retirement and being at the top of a company's career. Such conditions make CFOs tend to maximize short-term decisions because they no longer expect a career or a higher position. The result of this study is not in line with the study by (Rashad, 2014), (Huang et al., 2012), (Sundaram and Yermack, 2007). They stated that more mature CFOs would not involve financial statement 
fraud because CFOs will maintain the security of their position in the company and have more ethical behavior, so be careful when making decisions.

Based on the result of this study, the company recruited the board of commissioners who were older than the CFO. The company can also maximize the role of the audit committee to avoid misstatement due to violations of the General Acceptable Accounting Principles (GAAP). Research conducted by (Sudarman and Hidayat, 2019) on the role of the gender audit committee on earnings management results in the female audit committee being more careful and obedient to policies in financial reporting. The statement also reinforced by research conducted by (Sukma and Bernawati, 2019) proved that the audit committee, which has more numbers, has an accounting education background and the frequency of audit committee meetings, which often will increase the effectiveness of the audit committee. Active audit committees can conduct strict supervision when preparing financial statements.

The result of statistical tests showed that $\mathrm{H} 2, \mathrm{H} 3$, and $\mathrm{H} 4$ rejected, which means that both the level of education, gender, and experience of the CFO does not affect financial reporting fraud. When viewed from the descriptive statistical result, it knows that the age of the CFO with the most extensive working experience owns by the CFO of PT Ultrajaya Milk Industry \& Trading Company Tbk. The company is a family company that is led and overseen by one family. (Rusmin and Evans, 2017) stated that $67 \%$ of companies listed in Indonesia are family-controlled companies. Referring to the result of research conducted by (Mardiana, 2015), companies that are controlled by the family will carry out active supervision for managers and other company officials so that the CFO will not commit fraud. The level of education has no predictable influence because the average degree of knowledge of the CFO is undergraduate and a graduate-level learning more about theory. During learning at the undergraduate level, a person will absorb more theory and less practice in the field so that it is likely that when someone enters the company, their skills are still not developed. Gender in CFO also does not affect financial reporting fraud. Based on the result of research conducted by (Liao et al., 2019) which proved that gender does not affect financial statement fraud because of the political problems that are more pronounced, especially in SOE companies. It makes the CFO will only be subject to politicization carried out in the company.

Meanwhile, the variable control showed that ROA has a positive effect on financial statement fraud. ROA is associated with pressure faced by management to achieve specific targets set by shareholders (Noble, 2019). Regarding company size, this result is in line with research conducted by (Hajek and Henriques, 2017), which proved that small companies tend to be involved in fraud. Leverage has a negative influence on financial reporting fraud allegedly because most companies in Indonesia are family companies so that the CFO will still present the financial statements in their actual condition.

\section{CONCLUSION}

This study aimed to examine the effect of the demographic characteristics of CFO with fraudulent financial reporting. The analysis showed that the age of the CFO has a positive impact on financial statement fraud. Simultaneously, the level of education, gender, and experience of the $\mathrm{CFO}$ does not affect financial reporting fraud. CFOs who have an 
older age will have negotiation skills with the board so that the CFO can communicate oversight conducted by the board.

This study contributed to provide insight into the influence of the demographic characteristics of $\mathrm{CFO}$ on fraudulent financial statements, given that $\mathrm{CFO}$ is directly responsible for the preparation and accuracy of published financial statements. For regulatory authorities regarding governance, the study results provided advice on maximizing the function of the audit committee to prevent CFOs from misstatements by deliberately violating GAAP. The company can hire a board of commissioners who are more mature than the CFO, so the CFO has a reluctance to have a supervisory board.

This study has a limitation that only examines the demographic characteristics of CFO that affect financial reporting fraud, even though those responsible for the accuracy of financial statements are the CEO and CFO. Further research can examine the demographic characteristics of CEOs against fraudulent financial reporting. Also, new research can use composite index measurements for demographic characteristics to determine the effect of overall demographic characteristics. Based on the result of the study indicated that the experience and leverage variables do not affect financial reporting fraud allegedly due to the characteristics of a family-controlled company. It can be a space for further research to examine the effect of family ownership on financial reporting fraud.

\section{REFERENCES}

ACFE Indonesia. (2017). Survai Fraud Indonesia 2016. Retrieved from Jakarta.

Barua, A., Davidson, L. F., Rama, D. V., and Thiruvadi, S. (2010). CFO gender and accruals quality. Accounting Horizons, 24(1), 25-39.

Bertrand, M., and Schoar, A. (2003). Managing with style: The effect of managers on firm policies. The Quarterly journal of economics, 118(4), 1169-1208.

Capezio, A., and Mavisakalyan, A. (2016). Women in the boardroom and fraud: Evidence from Australia. Australian Journal of Management, 41(4), 719-734.

Cheng, L. T., Chan, R. Y., and Leung, T. (2010). Management demography and corporate performance: Evidence from China. International Business Review, 19(3), 261-275.

Daboub, A. J., Rasheed, A. M., Priem, R. L., and Gray, D. (1995). Top management team characteristics and corporate illegal activity. Academy of Management review, 20(1), 138-170.

Dechow, P. M., Ge, W., Larson, C. R., and Sloan, R. G. (2011). Predicting material accounting misstatements. Contemporary accounting research, 28(1), 17-82.

Francis, B., Hasan, I., Park, J. C., and Wu, Q. (2015). Gender differences in financial reporting decision making: Evidence from accounting conservatism. Contemporary Accounting Research, 32(3), 1285-1318.

Hajek, P., and Henriques, R. (2017). Mining corporate annual reports for intelligent detection of financial statement fraud-A comparative study of machine learning methods. Knowledge-Based Systems, 128, 139-152.

Hambrick, D. C., and Mason, P. A. (1984). Upper echelons: The organization as a reflection of its top managers. Academy of Management review, 9(2), 193-206.

Hartomo, G. (2019). Kronologi Kasus Laporan Keuangan Garuda Indonesia hingga Kena Sanksi.

Retrieved

from 
https://economy.okezone.com/read/2019/06/28/320/2072245/kronologi-kasuslaporan-keuangan-garuda-indonesia-hingga-kena-sanksi.

Heminway, J. M. (2007). Sex, trust, and corporate boards. Hastings Women's LJ, 18, 173.

Huang, H.-W., Rose-Green, E., and Lee, C.-C. (2012). CEO age and financial reporting quality. Accounting Horizons, 26(4), 725-740.

Liao, J., Smith, D., and Liu, X. (2019). Female CFOs and accounting fraud: Evidence from China. Pacific-Basin Finance Journal, 53, 449-463.

Mardiana, A. (2015). Effect Ownership, Accountant Public Office, and Financial Distress to the Public Company Financial Fraudulent Reporting in Indonesia. Journal of Economics and Behavioral Studies, 7(2), 109-115.

Nasution, D., and Jonnergård, K. (2017). Do auditor and CFO gender matter to earnings quality? Evidence from Sweden. Gender in Management: An International Journal, 32(5), 330-351.

Noble, M. R. (2019). Fraud diamond analysis in detecting financial statement fraud. The Indonesian Accounting Review, 9(2).

Ortiz-de-Mandojana, N., Bansal, P., \& Aragón-Correa, J. A. (2019). Older and Wiser: How CEOs' Time Perspective Influences Long-Term Investments in Environmentally Responsible Technologies. British Journal of Management, 30(1), 134-150. doi:10.1111/1467-8551.12287.

Papadimitri, P., Pasiouras, F., Tasiou, M., and Ventouri, A. (2020). The effects of board of directors' education on firms' credit ratings. Journal of Business Research, 116, 294313. doi:https://doi.org/10.1016/j.jbusres.2020.04.059.

Peraturan Otoritas Jasa Keuangan Nomor 75 /Pojk.04/2017 Tentang Tanggung Jawab Direksi Atas Laporan Keuangan, (2017).

Price, M., and Norris, D. M. (2009). White-collar crime: Corporate and securities and commodities fraud. Journal of the American Academy of Psychiatry and the Law Online, 37(4), 538-544.

Rashad Abdel-Khalik, A. (2014). CEO risk preference and investing in R \& D. Abacus, 50(3), 245-278.

Rusmin, R., and Evans, J. (2017). Audit Quality and Audit Report Lag: Case of Indonesian Listed Companies. Asian Review of Accounting, 25(2), 191-210. Retrieved from https://www.emeraldinsight.com/doi/abs/10.1108/ARA-06-2015-0062.

SOX Section 302: Corporate Responsibility for Financial Reports, (2002).

Schnatterly, K., Gangloff, K. A., \& Tuschke, A. (2018). CEO Wrongdoing: A Review of Pressure, Opportunity, and Rationalization. Journal of Management, 44(6), 24052432. doi:10.1177/0149206318771177.

Sproten, A. N., Diener, C., Fiebach, C. J., and Schwieren, C. (2018). Decision making and age: Factors influencing decision making under uncertainty. Journal of Behavioral and Experimental Economics, 46, 76, doi:https://doi.org/10.1016/j.socec.2018.07.002.

Subramanyam, K. (2014). Financial statement analysis (Eleventh Edition ed.): Includes index.

Sudarman, W. A., and Hidayat, W. (2019). Audit Committee and Earnings Management: The Role of Gender. Jurnal Akuntansi, 23(3), 379-392.

Sukma, P., and Bernawati, Y. (2019). The Impact of Audit Committe Characteristics on Audit Quality. Jurnal Akuntansi, 23(3), 363-378. 
Sun, J., Kent, P., Qi, B., and Wang, J. (2017). Chief financial officer demographic characteristics and fraudulent financial reporting in China. Accounting \& Finance.

Sundaram, R. K., and Yermack, D. L. (2007). Pay me later: Inside debt and its role in managerial compensation. The Journal of Finance, 62(4), 1551-1588.

Troy, C., Smith, K. G., and Domino, M. A. (2011). CEO demographics and accounting fraud: Who is more likely to rationalize illegal acts? Strategic Organization, 9(4), 259282.

Xu, Q., Fernando, G. D., and Tam, K. (2018). Executive age and the readability of financial reports. Advances in Accounting, 43, 70-81. doi:https://doi.org/10.1016/j.adiac.2018.09.004.

Yuehua, X., Lin, Z., and Honghui, C. (2018). Board age and corporate financial fraud: An interactionist view. Long Range Planning, 51(6), 815-830.

Zhang, X., Bartol, K. M., Smith, K. G., Pfarrer, M. D., and Khanin, D. M. (2008). CEOs on the edge: Earnings manipulation and stock-based incentive misalignment. Academy of Management Journal, 51(2), 241-258. 